\title{
Tutela estatística? Pontos de vista indígenas em relação aos dados produzidos sobre eles
}

\author{
Statistical tutorship? Indigenous people's points of view on the \\ data produced about them
}

\author{
¿Tutela estadística? Puntos de vista indígenas acerca de datos \\ generados sobre ellos
}

INDIGENOUS DATA SOVEREIGNTY: TOWARD AN AGENDA. Kukutai T, Taylor J, editors. Canberra: Australian National University Press; 2016. 320 p. (CAEPR Research Monograph, 38) ISBN 9781760460310.

doi: 10.1590/0102-311X00139418

Lançada em 2016, Indigenous Data Sovereignty: Toward an Agenda 1 é uma coletânea de textos que apresenta discussões travadas em torno da questão da aquisição de uma soberania de dados pelos povos indígenas. Com grande parte dos capítulos elaborados por autores indígenas, destaca a importância da apropriação pelos indígenas de estatísticas produzidas sobre eles. Os autores e autoras são membros de organizações voltadas para a questão indígena, além de órgãos públicos e universidades da Nova Zelândia, Austrália, Estados Unidos e Canadá. A discussão surge no momento em que a chamada "revolução dos dados” passa por críticas e questionamentos sobre segurança, preservação e confidencialidade de informações armazenadas em ambientes virtuais. Em meio a esse debate, o conceito de soberania de dados surge da demanda dos estados, empresas e cidadãos de imporem domínio sobre diversos tipos de informações.

Os capítulos da coletânea ampliam a questão para um nível que engloba não apenas o controle das informações, mas também a participação nos processos de produção de dados. Acima de tudo, os autores e as autoras destacam a importância de se repensarem os dados sobre indígenas, construindo informações que sejam realmente significativas para eles.

O livro é organizado por Tahu Kukutai, indígena, professora da Universidade de Waikato, na Nova Zelândia, e John Taylor, professor da Australian National University. Segundo os organizadores, esse seria o primeiro livro sobre soberania de dados indígenas que adota a ótica dos indígenas sobre o tema.

O livro está dividido em quatro partes. A primeira, Decolonising Indigenous Data, contempla aspectos históricos da discussão. No capítulo 2, Megan Davis, contextualiza o surgimento da questão da soberania de dados, surgida dos debates sobre direitos dos indígenas travados no âmbito das Nações Unidas. Nesse contexto, a existência de dados relevantes sobre os povos indígenas surge como "precondição vital", nas palavras da autora, para a elaboração de políticas voltadas para essas populações. No capítulo 3, Matthew Snipp discute o significado da expressão "soberania de dados" para os próprios indígenas. Estando englobados por estados-nação, os povos indígenas são desfavorecidos em temos de poder frente às sociedades que os circundam e, por isso estão sujeitos à uma espécie de "suserania de dados”. No capítulo 4, Ian Pool mostra que outras formas de dados sobre os indígenas já existiam na era pré-colonial, tendo sido substituídos pelos sistemas de dados dos colonizadores em uma relação de poder bastante desigual. 
Na segunda parte do livro, Critiques of Oficial Statistics, há três capítulos que analisam aspectos conceituais das estatísticas sobre indígenas. No capitulo 5, Maggie Walter discute questões epistemológicas sobre estatísticas populacionais. Segundo ela, os dados carregam significados derivados das normas sociais dominantes, racialmente hierarquizadas. Do mesmo modo, Frances Morphy critica as "categorias demográficas" atualmente usadas para definição de povos indígenas no capítulo 6. Afirma que os processos de quantificação calcam-se em uma "ontologia moderna" que colocaria o "real" como algo coextensivo ao "mensurável”, o que, nas palavras da autora, não atende aos anseios por apresentar a totalidade das condições de vida dos indígenas. No capítulo 7, Diane Smith tenta dar uma resposta efetiva para a construção de soberania de dados indígenas, partindo da reflexão conceitual sobre a efetividade da governança dos indígenas sobre seus dados. Segundo a autora, na prática, critérios etnocêntricos impõe relações causais equivocadas e simplificam complexidade social dos indígenas.

A terceira parte do livro, Data Sovereignty in Practice, apresenta exemplos de estratégias adotadas por alguns povos indígenas para garantir a soberania de dados. No capítulo 8, Ceal Tournier mostra a experiência das "primeiras nações" do Canadá na criação da marca registrada OCAP (propriedade [ownership, na sigla em inglês], controle, acesso e posse), criada para garantir a soberania de dados indígenas no país. São apresentados os caminhos do processo de certificação adotados em uma pesquisa em saúde realizada sobre comunidades tradicionais do Canadá. Tratando da Nova Zelândia, no nono capítulo Maui Hudson, Dickie Farrar \& Lesley McLean elaboram aspectos chave para a soberania de dados sob perspectiva tribal local. Para isso, descrevem o crescente interesse tribal de uso de dados na Nova Zelândia, país em que a participação dos indígenas em diversas esferas da sociedade tem crescido de forma considerável. Contudo, mesmo sendo a Nova Zelândia uma referência quanto à criação de arcabouços sobre gestão e uso de dados sobre indígenas, os autores destacam os desafios ainda existentes para garantir a efetividade da questão. No capítulo 10, James Hudson apresenta os debates entre maoris e não maoris no Conselho Municipal de Auckland sobre o significado de "viver bem" na cidade. Mostra os problemas relacionados à escassez de dados referentes aos maoris, assim como desafios para criação de dados sobre bem-estar maori segundo seu próprio ponto de vista. Também tratando da questão maori, no décimo primeiro capítulo Rawiri Jansen destaca as oportunidades surgidas na Nova Zelandia a partir do crescimento de uma "classe profissional indígena", especialista em produção e uso dados. A partir de uma pesquisa sobre saúde dos maori, mostra um exemplo prático da possibilidade de se uso de dados para desconstruir o racismo institucional vigente naquele país. No capítulo 12, Ray Lovett destaca a participação dos indígenas da Austrália no desenvolvimento de um "arcabouço cultural" criado para mensurar o bem-estar dos aborígenes e comunidade das ilhas do Estreito de Torres segundo seu próprio ponto de vista. Seguindo a mesma linha, no capítulo 13, Mandy Yap \& Eunice Yu mostram outro exemplo australiano de busca de soberania de dados indígenas em nível local, na região de Brome, a partir de uma pesquisas realizadas pelos indígenas para mensuração de bem -estar sob sua própria ótica. No capítulo 14, Desi Rodriguez-Lonebear apresenta os resultados de entrevistas feitas com líderes tribais norte-americanos mostrando que, sob a ótica deles, já viveram numa era de soberania de dados, mas se tornaram dependentes após a colonização.

Na quarta e última parte, State Agency Responses, há dois capítulos dedicados ao posicionamento de institutos oficiais de estatística da Austrália e Nova Zelândia sobre estatísticas indígenas. No capítulo 15, Paul Jelfs mostra o envolvimento de indígenas australianos nas atividades do Australian Bureau of Statistics. Já no capítulo 16, Dan Bishop destaca a participação dos maoris na produção de informações na Nova Zelândia.

Em termos gerais, os capítulos destacam o papel dos indígenas na definição de quais os 
aspectos de sua organização social devem ser mensurados em pesquisas e registros estatísticos. Além disso, outro aspecto importante que perpassa as discussões diz respeito às possibilidades de desagregação das informações para unidades de análise representativas $\mathrm{d}$ a realidade indígena.

As estatísticas são processo de extrema simplificação de realidades complexas. Uma demografia indígena deveria então tornar visível formas diferentes de estar no mundo e legitimar o direito de ser diferente, ao invés de ranquear todos indivíduos segundo um mesmo padrão cultural.

Embora promissor, esse discurso mostra que atingir a soberania de dados indígenas trará desafios práticos e epistemológicos para instituições e campos disciplinares envolvidos com a produção de dados.
Marden Barbosa de Campos 1

1 Departamento de Sociologia, Universidade Federal de Minas Gerais, Belo Horizonte, Brasil.

mardencampos@gmail.com

1. Kukutai T, Taylor J, editors. Indigenous data sovereignty: toward an agenda. Canberra: Australian National University Press; 2016. (CAEPR Research Monograph, 38). 